\title{
Kontrol Diri Wanita Terhadap Keinginan Merokok
}

\author{
Anik Sunariyati Siswoyo, Umi Dayati, Muh. Ishom Ihsan \\ Universitas Negeri Malang, Jl. Semarang No. 5 Malang, Jawa Timur, Indonesia \\ *Penulis korespondensi, Surel: anik.sunariyati.1701416@students.um.ac.id
}

Paper received: 25-8-2021; revised: 8-9-2021; accepted: 15-9-2021

\begin{abstract}
Many women found smoking casually smoking in public places and even in the campus canteen. This paper tries to review women's self-control over the desire to smoke, especially for female students majoring in Out-of-school Education in Malang City. The study used a qualitative approach, data was collected through observation, in-depth interviews, and documentation. Then data reduction is simplified, and data presentation is organized in an organized manner. The validity of the data was checked using a triangulation technique of sources, theories and methods. The results of this study indicate that women's desire to smoke is influenced by different factors, as well as differences in selfcontrol in each individual. The results showed that there were two factors that caused female students to smoke, including the family environment and the friendship environment. The selfcontrol of smoking female students differed from the three informants, namely low self-control (under control), excessive self-control (over control), and appropriate self-control (Appropriate Control).
\end{abstract}

Keywords: self control; desire; smoking woman

\begin{abstract}
Abstrak
Banyak ditemukan wanita merokok dengan santai merokok ditempat umum bahkan di kantin kampus. Tulisan ini berusaha mengulas tentang bagaimana kontrol diri wanita terhadap keinginan merokok, khususnya pada mahasiswa jurusan Pendidikan Luar Sekolah di Kota Malang. Penelitian menggunakan pendekatan kualitatif, data dikumpulkan melalui observasi, wawancara mendalam, serta dokumentasi. Kemudian reduksi data dengan disederhanakan, serta penyajian data dengan menyusun secara terorganisir. Keabsahan data diperiksa menggunakan teknik triangulasi sumber, teori dan metode. Hasil penelitian ini menunjukkan bahwa keinginan wanita merokok dipengaruhi oleh faktor yang berbeda, juga dengan adanya perbedaan kontrol diri pada setiap individu. Hasil penelitian menunjukan ada dua faktor penyebab mahasiswi merokok diantaranya faktor lingkungan keluarga dan lingkungan pertemanan. Kontrol diri mahasiswi merokok berbeda dari ketiga informan, yakni kontrol diri yang rendah (under control), kontrol diri yang berlebihan (over control), dan kontrol diri tepat (appropriate control).
\end{abstract}

Kata kunci: kontrol diri; keinginan; wanita merokok

\section{Pendahuluan}

Merokok di Indonesia menjadi hal yang sangat biasa dilakukan dimanapun bahkan dilihat secara langsung oleh anak-anak. Salah satu faktor utama yang menjadikan banyaknya perokok di Indonesia adalah karena rokok dijual secara bebas, yang mana penjual dan pembeli rokok tidak dibatasi siapapun, baik itu anak dibawah umur, remaja dan orangtua. Hal ini mendukung orang Indonesia untuk mudah mendapatkannya. Meskipun larangan merokok sudah di atur dalam Undang-Undang, bahkan jelas tertulis dalam setiap kemasan rokok tentang bahaya merokok, namun kandungan zat yang ada di dalam setiap batang menjadikan orang kecanduan dan ingin terus mencarinya lagi dan lagi. Hal ini juga disebabkan karena tidak seimbangan jumlah perokok dan harga pajak tembakau di Indonesia, sehingga Indonesia 
menjadi salah satu negara dengan jumlah perokok tertinggi di ASEAN. Perokok Indonesia mencapai 65\% laki-laki dan 21\% perokok wanita (Suhendra, 2017).

Menurut data dari Kementerian Kesehatan Republik Indonesia, prevalensi perokok wanita juga meningkat dari 4,2\% pada tahun 1995 menjadi 6,7\% pada tahun 2013. Oleh karena itu, pada 20 tahun yang lalu, empat dari seratus wanita di Indonesia adalah perokok. Serta ada tujuh dari seratus wanita Indonesia saat ini perokok (Kemenkes, 23 Januari 2021).

Merokok juga dapat dilihat dari berbagai perspektif, dari perspektif kesehatan, ekonomi, lingkungan, dan agama. Banyak dari pandangan tersebut menunjukkan bahwa merokok memiliki dampak yang negatif khususnya pada kesehatan. Dari segi kesehatan merokok dapat menimbulkan berbagai penyakit yang dapat merugikan kesehatan perokok itu sendiri dan orang-orang di sekitarnya. Dari sudut pandang psikologi, akibat dari merokok adalah ekstroversi implusif, yang dapat mengambil risiko dan menyebabkan perilaku tertentu yang banyak bergerak dan menjadi tegang (Ma'sum dalam Lake, 2018).

Perilaku merokok yang terjadi pada wanita telah menjadi perdebatan tentang kelayakannya di komunitas tertentu tertentu, yang akhirnya memunculkan beberapa anggapan. Merokok bukanlah hal yang umum dan lazim dilakukan oleh wanita, karena wanita yang merokok dianggap sebagai karakteristik yang membedakan mereka dari wanita-wanita lain yang tidak merokok. Seiring dengan perkembangan masyarakat yang semakin modern, kebiasaan merokok saat ini tidak lagi dianggap tabu dalam kehidupan masyarakat. Tuntutan gaya hidup yang modern, membuat anggota masyarakat khususnya kaum wanita mencoba halhal baru dalam hidupnya. Dalam hal ini tentunya banyak faktor yang menjadi penyebab wanita akhirnya memilih untuk merokok.

Berdasarkan hal tersebut maka peneliti akan membahas tentang kontrol diri wanita terhadap keinginan merokok pada mahasiswi jurusan pendidikan. Peneliti berharap dengan dilakukannya penelitian ini dapat memberikan wawasan yang mendalam mengenai kontrol diri wanita terhadap keinginan merokok mahasiswi jurusan Pendidikan Luar Sekolah.

\section{Metode}

Penelitian ini menggunakan pendekatan kualitatif. Jenis penelitian yang digunakan dalam penelitian ini adalah kualitatif deskriptif, yang bertujuan untuk menganalisa tentang sebuah kasus kontrol diri mahasiswi yang hubungannya dengan keinginan merokok. Penelitian ini menggunakan teknik pengumpulan data melalui wawancara mendalam. Peneliti melakukan penelitian ini dengan memilih studi kasus tertentu yaitu mahasiswi perokok. Peneliti melakukan wawancara secara personal kepada mahasiswi merokok yang dijadikan informan dengan maksud memperkenalkan diri dan mempertanyakan kesediaan informan dijadikan sebagai sumber data peneliti. Selanjutnya, dengan izin informan, peneliti memberikan pertanyaan-pertanyaan berkaitan dengan penelitian secara bertahap. Pada penelitian ini kehadiran peneliti sangat berperan penting dalam proses penelitian. Data dikumpulkan oleh peneliti berdasarkan hasil observasi yang dilakukan secara tidak langsung melalui pengamatan pada profile sosial media informan. Peneliti menemukan fakta bahwa informan menunjukkan perilaku merokok melalui foto yang diupload pada sosial media.

Data yang dikumpulkan oleh peneliti berdasarkan hasil dokumentasi adalah foto mahasiswi yang merokok di cafe sebagai acuan perilaku merokok pada mahasiswi di tempat umum. 
Selanjutnya pada proses reduksi data, yang mana data yang pokok diidentifikasi dengan tujuan untuk memfokuskan kepada objek dalam penelitian dan memberikan kode pada setiap data yang ditemukan.

\section{Hasil dan Pembahasan}

\subsection{Hasil}

Hasil analisis data pada penelitian ini bertujuan untuk mencari data tentang faktorfaktor yang menyebabkan mahasiswi merokok, dan perbedaan kontrol diri mahasiswi terhadap keinginan merokok sebagai berikut

\subsubsection{Faktor-faktor Penyebab Mahasiswi Merokok}

Pembelajaran melalui pengamatan meniru perilaku orang lain meskipun tidak mendapatkan penguatan positif maupun negatif merupakan suatu proses pembelajaran yang tidak akan didapat dalam pembelajaran kelas formal. Orang lain memperlihatkan sesuatu yang ingin dipelajari oleh pengamat dan mengharapkan mendapat pujian atau penguatan apabila menguasai secara tuntas apa yang dipelajari. Begitu juga dengan wanita merokok, perilaku tersebut juga didapatkan dari adanya pengamatan yang dilakukan sehingga mempengaruhi pelaku untuk mencoba-coba.

Meskipun secara tidak langsung proses belajar meniru pada wanita merokok sejatinya benar-benar ada. Proses belajar inilah yang menjadi faktor penyebab sehingga mahasiswi merokok. Selain faktor meniru, faktor lain yang menyebabkan mahasiswi merokok adalah faktor kesenangan. Karena rasa yang senang terhadap aroma ataupun rasa rokok menjadikan mahasiswi menjadi seorang perokok. Bukan hanya itu saja, teman juga menjadi salah satu faktor yang menyebabkan mahasiswi merokok, yang mana teman mempunyai pengaruh besar terhadap kebiasaan seseorang.

Teman bisa memberikan dampak yang baik maupun buruk terhadap setiap individu. Teman terkadang menjadi alasan seseorang untuk melakukan suatu hal. Penelitian ini, teman menjadi salah satu faktor yang menyebabkan mahasiswi merokok, yang mana seorang teman mencoba untuk menawarkan rokok terhadap informan dan pada akhirnya disetujui meskipun tanpa ada pemaksaan. Selain mencoba untuk menawarkan, teman perkumpulan pertemanan juga menjadi faktor penyebab, yang mana dalam data dihasilkan adanya rasa penasaran karena teman-temannya juga adalah seorang perokok.

\subsubsection{Perbedaan Kontrol Diri wanita Merokok}

Dari ketiga mahasiswi yang menjadi informan penelitian, diketahui bahwa ketiga informan merupakan perokok aktif, namun ketiga informan memiliki perbedaan pada kurun waktu lamanya merokok, kurang dari enam bulan merokok, satu tahun merokok dan juga perokok aktif yang lebih dari dua tahun. Selain berbeda faktor penyebab, lamanya merokok juga mempengaruhi perbedaan kontrol diri dari masing-masing. Perbedaan kontrol diri pada masing-masing informan juga berbeda penyebabnya, yakni penyebab yang berasal dari diri sendiri, lingkungan keluarga dan juga lingkungan pertemanan. Hal ini berarti, lingkungan memiliki pengaruh yang besar terhadap cara individu yang pada hal ini yakni mahasiswi untuk mengontrol atau mengendalikan diri terhadap keinginan untuk merokok. Adanya perbedaan 
kontrol diri disebabkan banyak hal. Perbedaan kontrol diri setiap informan disebabkan karena lingkungan, lingkungan yang mendukung seseorang untuk merokok akan memperkecil kemungkinan untuk mengontrol agar tidak merokok. begitu juga sebaliknya, lingkungan yang tidak mendukung individu untuk merokok akan menjadi peluang besar bagi individu untuk mengontrol diri.

Selain dari faktor lingkungan, peneliti menemukan hasil bahwa perbedaan kontrol diri terhadap merokok karena individu yang mampu mengendalikan, yang mana informan menyampaikan bahwa keinginan merokok rendah karena hanya merokok ketika merasa tidak nyaman dengan perasaannya. Kemudian, kontrol diri yang rendah karena merokok sudah menjadi hal yang biasa dan terbiasa dilakukan.

Motivasi untuk berhenti merokok menjadi penyebab perbedaan kontrol diri, karena dari hal tersebut dapat diketahui bahwa informan yang rata-rata tidak ingin berhenti merokok tetapi hanya mengurangi saja.

\subsection{Pembahasan}

\subsubsection{Faktor-faktor Penyebab Mahasiswi Merokok}

Faktor-faktor yang mempengaruhi seseorang merokok menurut Sarafino dalam Ani (2017) diantaranya Faktor sosial yang mana seorang individu akan menyesuaikan diri dengan yang lain atau sebaliknya, sehingga menyebabkan perilaku setiap individu tidak terlepas dari lingkungan sosial keluarga maupun teman sebaya.

Secara tidak sadar, mahasiswi merokok dipengaruhi oleh lingkungan. Lingkungan yang mempengaruhi masing-masing individu berbeda-beda. Seperti halnya anggapan bahwa dengan merokok informan lebih mudah mampu bergaul dengan teman-teman dan dapat dengan mudah memperluas circle pertemanan. Faktor pertemanan menjadi alasan terkuat yang melatarbelakangi perilaku merokok pada mahasiswi. Perilaku merokok tersebut dapat menimbulkan dampak positif serta negatif. Mulai dari kesenangan dan ketenangan hingga faktor kesehatan dan juga penilaian dari masyarakat sekitar.

Teori Sarafino sebagai teori faktor penyebab mahasiswi merokok, faktor tersebut diantaranya adalah faktor sosial yang berasal dari keluarga dan juga lingkungan pertemanan. Berdasarkan hasil pemaparan data pada bab sebelumnya, mahasiswi merokok dengan kurun waktu lebih dua tahun disebabkan faktor lingkungan keluarga, sehingga mahasiswi menjadi seorang perokok. Selain menjadi faktor penyebab, lingkungan keluarga juga menjadi faktor pendukung, sehingga mahasiswi merokok tetap mempertahankan kebiasaan merokok.

Selain dari faktor keluarga, teori Sarafino juga menjelaskan bahwa faktor sosial juga terdiri dari faktor lingkungan masyarakat atau teman bergaul. Peneliti telah memaparkan data pada bab sebelumnya, hasil penelitian menjelaskan faktor yang menyebabkan mahasiswi merokok terdiri dari faktor lingkungan pertemanan atau lingkungan pergaulan, hal ini terdapat pada mahasiswi merokok dengan kurun waktu satu tahun dan kurang dari enam bulan. 


\subsubsection{Perbedaan Kontrol Diri wanita Merokok}

Perbedaan kontrol diri setiap individu disebabkan karena setiap individu memiliki tujuan dan kebutuhan yang berbeda. Averill (1973) menjelaskan bahwa kontrol diri memiliki sifat memodifikasi perilaku, mengelola perilaku yang diyakini serta diinginkan. Menurut Gufron (2010), terdapat tiga tingkatan kontrol diri.

Berdasar hasil penelitian menemukan fakta bahwa informan memiliki kontrol diri yang berbeda-beda, perbedaan kontrol diri pada informan disebabkan pengaruh lingkungan dan juga kondisi, yang dimana setiap masing-masing informan berada pada lingkungan dan kondisi yang berbeda-beda dan terbagi kedalam tiga jenis kontrol diri antara lain:

\subsubsection{Over control}

Over control terdapat pada mahasiswi yang merokok kurang dari enam bulan, yang menjelaskan bahwa dirinya merokok karena mendapat masalah, sehingga informan melampiaskan perasaan melalui merokok. Over control atau kontrol diri yang berlebih pada informan kurang dari enam bulan merokok diperoleh dari hasil wawancara yang menjelaskan bahwa informan tidak merokok secara berkala, informan juga menyampaikan bahwa membeli rokok ketika memiliki uang dan hanya ketika ingin saja, meminta rokok kepada teman hanya sesekali apabila rokoknya cocok dengan informan. Selanjutnya, informan juga sangat jarang merokok, yang berarti informan bukan termasuk pecandu rokok. Menurut informan rokok hanya sebagai kesenangan sesaat sebagai penghilang overthinking sesaat saja. Namun, informan tidak berpotensi untuk berhenti merokok hanya saja mengurangi mengkonsumsi rokok. Dapat dikatakan over control karena informan dapat mengendalikan dirinya untuk tidak merokok secara berkala, dan keinginannya untuk merokok termasuk kedalam kategori rendah, hal ini dikarenakan responden tidak berusaha keras untuk dapat menikmati rokok.

\subsubsection{Under control}

Under control atau disebut juga kontrol diri yang rendah terdapat pada mahasiswi merokok lebih dari dua tahun, hasil dari paparan data didapat bahwa mahasiswi perokok lebih dari dua tahun cenderung sering mengkonsumsi rokok dan penghabis terbanyak daripada informan yang lainnya rokok setiap harinya. Dari penjelasan bahwa mahasiswi perokok lebih dari enam bulan dapat merokok dimanapun Ia berada, di rumah bahkan pernah juga merokok di kampus. Setiap hari menghabiskan satu pack rokok berisi 12-16 batang rokok, merokok dianggap teman ngobrol lebih santai termasuk kedalam kontrol diri yang rendah.

\subsubsection{Appropriate Control}

Appropriate control atau kontrol diri yang dilakukan secara tepat, terjadi pada mahasiswi merokok dengan kurun waktu satu tahun merokok. ketepatan ini dibuktikan dengan kontrol diri yang dilakukan informan ketika berada dirumah tidak merokok meskipun mempunyai kesempatan untuk merokok. Namun, informan hanya merokok ketika tidak berada dirumah, merokok ketika mengerjakan tugas dan berkumpul dengan teman-teman tertentu. Informan menghabiskan rokok 1 pack isi 12-16 batang bisa hingga 4-5 hari, yang artinya setiap hari informan rata-rata menghabiskan 2-3 batang rokok per harinya. 


\section{Simpulan}

Berdasarkan hasil penelitian dan pembahasan yang telah dikemukakan, dapat disimpulkan beberapa hal sebagai berikut: (1) Faktor-faktor yang menyebabkan mahasiswi Jurusan Pendidikan Luar Sekolah merokok diantaranya adalah faktor sosial yang terdiri dari lingkungan keluarga dan juga lingkungan pertemanan. (2) Kontrol diri mahasiswi merokok berbeda dari ketiga informan, yakni kontrol diri yang rendah ( under control) didapat pada mahasiswi yang merokok lebih dari dua tahun, hal ini disebabkan karena lingkungan pertemanan dan juga keluarga tidak terlalu memperdulikan perilaku merokok informan, dengan artian lain keluarga infroman mendukung perilaku merokok informan. Kemudian, kontrol diri yang berlebihan (over control) didapat pada mahasiswi merokok dengan kurun waktu kurang dari enam bulan, hal ini disebabkan karena mahasiswi merokok kurang dari enam bulan tidak bergantung pada rokok, informan hanya menjadikan rokok sebagai hiburan ketika informan merasa overthinking, dan apabila informan merasa ingin. Selanjutnya Appropriate Control atau disebut dengan kontrol diri yang tepat terdapat pada mahasiswi merokok dengan kurun waktu satu tahun, hal ini disebabkan karena faktor keluarga tidak mendukung dan informan menyembunyikan kebiasaan merokoknya terhadap di hadapan keluarga.

\section{Daftar Rujukan}

Fitri, R. A. (2013). Gambaran Disonansi Kognitif pada Wanita Perokok Dewasa Muda Berpendidikan Tinggi. Humaniora, 4(1), 547.

Gaga, R., Joko, W., \& Erlisa, C. (2017). Hubungan lingkungan sosial dengan perilaku merokok pada wanita di kota Malang. Nursing News, 2(2), 749-760.

Kusumadewi, S., Hardjajani, T., \& Priyatama, A. N. (2012). Hubungan Antara Dukungan Sosial Peer Group dan Kontrol Diri dengan Kepatuhan terhadap Peraturan pada Remaja Putri di Pondok Pesantren Modern Islam Assalam Sukoharjo. Jurnal Ilmiah Psikologi Candrajiwa, 1(2), 1-10.

Lake, W. R. R., Hadi, S., \& Sutriningsih, A. (2018). Hubungan Komponen Perilaku (Pengetahuan, Sikap, Tindakan) Merokok pada Mahasiswa. Nursing News, 2(3), 843-856.

Moleong, L. (2016). Metodologi Penelitian Kualitatif. Penerbitan PT Remaja Rosdakarya Bandung.

Sugiyono, (2014). Memahami Penelitian Kualitatif. CV. alfabeta Bandung.

Suhendra, (2017). Prestasi Rokok Indonesia di ASEAN. Tirto.id 